\title{
A Case Study On some aspects of statistical analysis: A case study approach
}

See end of the paper for authors' affiliations

Correspondence to :

Ashok J. Shivagaje

P.G. Department of

Statistics, New Arts

Commerce and Science

College, Ahmednagar

(M.S.) India

Email : ashokjs123@

gmail.com

\section{Paper History :}

Received : 30.05.2018;

Accepted : 06.09.2018
ABSTRACT : Due to the advent of low cost advanced ICT and software availabilities various organizations are creating data ware houses and thereby maintaining large dimensional, multivariate, valuable data as an asset. Therefore, a large number of carrier opportunities in data analysis in the capacity of data scientists are emerging. In order to cope up with the market demand of data scientists, academia are updating their syllabi by introducing various statistical analysis softwares, computer based practical's and at least one semester project. The objective of this paper is to bring these critical issues to the notice of academies', researchers and data analysts. The paper also gives discussion regarding resolving these issues. Further, statistical theories and concepts involved in data analysis is thoroughly discussed through a case study in management science. The results of the data analysis in the proposed case study indicates that peoples by and large gives priority of expenditure as food, clothing and shelter. This finding is highly consistent with the basic needs discussed in many economic theories. Further, to achieve the family and personal goals the first priority is given to saving and last to sale of agriculture land.

KEY WORDS : Exploratory, Explanatory, Confirmatory, Data analysis

HOW TO CITE THIS PAPER : Shivagaje, Ashok J., Kasture, Madhukar S., Shelake, C.G. and Nalavade, A.J. (2018). On some aspects of statistical analysis: A case study approach. Res.J. Agric. Eco. \& Stat., 9 (2) : 399-406, DOI : 10.15740/HAS/IRJAES/9.2/399-406. Copyright@ 2018: Hind Agri-Horticultural Society. 